\title{
The resignification as part of logotherapy, for the well-being of young people in a situation of addiction annexation
}

\section{La resignificación como parte de la logoterapia, para el bienestar de jóvenes en situación de anexo por adicciones}

CEJAS-LEYVA, Luz María $\dagger^{1}$, CALDERÓN-PALENCIA, Laura Araceli*2, VILLAZANAMARTÍNEZ, Jesús Salvador ${ }^{3}$ and HERNÁNDEZ-SÁCHEZ, Eréndira ${ }^{4}$

\author{
${ }^{I}$ Fomento Educativo Para el Desarrollo del Potencial Humano "Silvestre Revueltas" FEIDEP \\ ${ }^{2}$ Facultad de Psicología y Terapia de la Comunicación Humana, UJED. \\ ${ }^{3}$ Facultad de Trabajo Social, UJED. \\ ${ }^{4}$ Universidad Autónoma de Durango, UAD.
}

ID $1^{\text {st }}$ Author: Luz María, Cejas-Leyva / ORC ID: 0000-0003-1822-5606, Researcher ID Thomson: V-3185-2019, CVU CONACYT ID: 889382

ID $1^{\text {st }}$ Coauthor: Laura Araceli, Calderón Palencia / ORC ID: 0000-0002-9016-6332, Researcher ID Thomson: ABC-91672020; CVU CONACYT ID: 1093628

ID $2^{\text {nd }}$ Coauthor: Jesús Salvador, Villazana Martínez / ORC ID: 0000-0003-1955-8859, Researcher ID Thomson: ABC8320-2020, CVU CONACYT ID: 1088120

ID $3^{\text {rd }}$ Coauthor: Eréndira, Hernández-Sánchez / ORC ID: 0000-0002-6698-1230, Researcher ID Thomson: ABC-83272020, CVU CONACYT ID: 1093677

DOI: $10.35429 /$ EJROP.2020.6.11.15.27

Received July 18, 2020; Accepted December 30, 2020

Abstract

Objective: Identify the self-perception of young people in a situation of addiction, drug use and the meaning of life, through a workshop focused on logotherapy. Methodology: Qualitative research, with which in addition to the collection of theoretical information on logotherapy and resignification; Data was collected from young people in a situation of addiction, participants of the workshop "The resignification of addiction" through a focus group conducted by FEIDEP specialists. Information that allowed contrasting data in the sections of results and conclusions. Contribución Contribution: Categories were elaborated that reveal the personal interpretation of the prevailing reality regarding the situation that young people live in a situation of addiction annexation, as well as the resignification of it by raising awareness of the possibility of freedom to choose through logotherapy. To achieve the above, the young participants externalized resources that enable a life project based on the capacity for change, motivations, attitudes and emotional skills, to achieve a situation of greater well-being.

Logotherapy, Resignification, Meaning of life

\begin{abstract}
Resumen
Objetivo: Identificar la autopercepción de los jóvenes en situación de anexo por adicciones, sobre el consumo de drogas y el sentido de vida, por medio de un taller centrado en la logoterapia. Metodología: Investigación de corte cualitativo, con la cual además de la recolección de información teórica sobre la logoterapia y la resignificación; se recopilaron datos de jóvenes en situación de anexo por adicciones, participantes del taller "La resignificación de la adicción" a través de un grupo focal efectuado por los especialistas de FEIDEP. Información que permitió contrastar datos en los apartados de resultados y conclusiones. Contribución: Se elaboraron categorías que revelan la interpretación personal, de la realidad que prevalece en cuanto a la situación que viven los jóvenes en situación de anexo por adicciones, así como la resignificación de la misma al concientizar la posibilidad de la libertad de elegir por medio de la logoterapia. Para lograr lo anterior los jóvenes participantes exteriorizaron recursos que posibilitan un proyecto de vida basado en la capacidad de cambio, motivaciones, actitudes y habilidades emocionales, para alcanzar una situación de mayor bienestar.
\end{abstract}

Logoterapia, Resignificación, Sentido de vida

Citation: CEJAS-LEYVA, Luz María, CALDERÓN-PALENCIA, Laura Araceli, VILLAZANA-MARTíNEZ, Jesús Salvador and HERNÁNDEZ-SÁCHEZ, Eréndira. The resignification as part of logotherapy, for the well-being of young people in a situation of addiction annexation. ECORFAN Journal-Republic of Paraguay. 2020. 6-10: 15-27

* Correspondence to Author (email: laura_pale@ hotmail.com)

$\dagger$ Researcher contributing as first author. 


\section{Introduction}

FEIDEP (Educational Promotion for the Development of Human Potential "Silvestre Revueltas") is a non-profit organization that emerged in the city of Durango, Dgo. Mexico, in 2009 , with the aim of supporting students in training as family therapists with courses, diplomas, workshops and supervision.

This article integrates the information derived from the actions carried out by this association, regarding the design, application and obtaining of results of the workshop "The resignification of addiction"

The activity was carried out with 15 young people in an annex situation due to addictions (all male and of legal age), who agreed to participate once the call was sent to Fundación Durango A.C. (place where they are receiving support for their rehabilitation). So the participants attended FEIDEP facilities on time and in good spirits to actively collaborate in the workshop.

\section{Justification}

The problems generated by drug dependence in young people bring with it the need for therapeutic services focused on the prevention and treatment of addictions, which respond to the problems derived from the use and abuse of drugs.

Currently, logotherapy, a therapeutic approach with great contributions and important advances for the treatment, among other cases, of people with addictions, is a field of action in the psychological field that allows identifying and putting into practice the resources that allow young people in a situation of annex for addictions, build a new dimension of life (Martínez, Castellanos, Osorio and Camacho, 2015, para. 1).

Likewise, publicizing intervention projects, in cases like the one in this article, becomes an opportunity to contribute to the dissemination of relevant data emanating from the actions carried out, for the care of these young people.

\section{Problem}

For the foundation "Hay Salida" (2020) in Madrid, Spain; addiction is a disease equated with other chronic diseases, such as diabetes, high blood pressure, asthma or cancer. Characterized by the inability to maintain abstinence, loss of impulse control, intense desire or craving for substance use, difficulty in recognizing the consequences derived from consumption, and dysfunctional emotional responses in interpersonal relationships (par. 13).

Likewise, the UN, cited by Villatoro, Medina-Mora, Fleiz, Moreno, Oliva, Bustos, Fregoso, Gutiérrez and Amador (2012) estimates that worldwide, around 230 million adults $(5 \%$ of this population) consumed an illicit drug at least once in 2010, while in Mexico in 2008 consumption in the population between 12 and 65 years old was $1.6 \%$, which places our country in the international context as one of the countries with a low level of consumption, although in turn, an increase in the problem is reported if the most recent national trends are analyzed (para. 12).

On the other hand, and according to the National Urban Security Survey (ENSU, 2018) cited by Guereca (2019); Durango is among the first eight cities in the country, where there is a perception of greater drug use and drug dealing (para. 1).

\section{Research questions}

What effects does logotherapy have on the selfperception of drug use and the meaning of life in young people in a situation of addiction addiction?

What role does the resignification of drug use and the meaning of life play in the care of young people in a situation of addiction addiction?

\section{Objective}

Identify the self-perception of young people in a situation of addiction addiction, on drug use and the meaning of life, through a workshop focused on logotherapy. 


\section{Theoretical framework}

The theoretical approach of this article begins with the antecedents of constructionism; theory linked to the construction of new perspectives subject to the metaphor of construction through discursive action (Agudelo and Estrada, 2012, p.375).

For López-Silva (2013) one of the philosophical influences of constructionism is found in the work of Kant, who proposed that our reality is in a sense a mental construction determined by the mental categories prior to the experience that we have (p. 10).

Marco Aurelio (Stoic philosopher) cited by Daza (1984), conceives that the true salvation of individual life and the community lies in practicing justice with the whole soul and in telling the truth, which he considers a supreme demand of the nature of man (p.289).

Likewise, as Linares ( $/ \mathrm{f}$ ) mentions in the face of existential discomfort, the vital potential of Stoic thought due to its depth and versatility, considers that dialogue is a response to the discomfort for which Stoicism (where belief, emotion and truth go hand in hand) also provides elements for the implementation of logotherapy (pp. 3-83).

\section{Constructionism}

Sandoval (2010) identifies constructionism as a theoretical-methodological position, with a social focus that is linked to the critique of deconstruction, to explore the types of relationships that can be established from new conceptions of the world and of ourselves ( $p$ $.33)$.

In this sense, constructionism denies the idea of a passively learned reality, which is why reality is considered an expression of the very structure of those who know. Thus, the subject actively participates in the process of construction of reality, whose construction is his own invention (López-Silva, 2013, p. 11).

Constructionism is itself an alternative perspective to individual therapeutic attention that allows shared analysis of reality. Ibañez (2001) cited by Sandoval (2010) affirms that the objective of this alternative is to carry out a critical exercise, for the development of a metaphor linked to construction (p.33).

\section{Social constructionism}

In turn, social constructionism has among its origins the works of Vigotsky and Bruner (historical-cultural theory that bases learning on the cognitive activity of the subject) who reveal that the mind constructs reality through the relationship with the world. Reality determined by the influence of the social relationships that the subject possesses when carrying out the constructive action (López-Silva, 2013, p. 12).

Social constructionism studies psychological phenomena from the way in which people apply their past experience to present circumstances. The social constructionist gaze proposes a way of approaching the complexity of reality, considering diversity and individuality as manifested by people (Donoso, 2004, p. 10).

Likewise, social constructionism maintains that the central point of therapy is in the construction of meaning and meaning for the individual in interaction with the context (Aristegui, 2015, p.121), in this case the construction of meaning, meaning of the addiction and the meaning of life of the addict.

\section{Logotherapy}

Logotherapy is a variant of psychotherapy, revolves around the presentation of the concept of will to meaning as the first motivation of man. It is a Viennese school framed in the field of psychology, behind the psychoanalysis promoted by Freud and the individual psychology developed by Alfred Adler (Pérez and Merino, 2012, par. 1).

Logotherapy helps each person to discover the meaning of life, to be aware of who they are (Iglesia, s / f, p.15). Through dialogue, in this intervention approach, the bases of the conflict emerge, therefore; Dialogue is considered the best option to deal with realities and their relationship with problems, and at the same time it is an excellent means for the generation of new realities, becoming the basis for visualizing new possibilities and alternative forms of action (Estrada and Diazgranados, 2007, pp. 333-348). 
From logotherapy, it is considered that there is a feeling of emptiness and a very deep reason for the choice and consumption of a drug, an environment that makes the individual vulnerable to drug use, as a means of escaping reality or as a substitute for fill the existing void (Gimeno, s / f, p. 6).

\section{Narrative approach}

The narrative therapeutic approach is installed within poststructuralist ideas. Some antecedents of narrative therapy include the contributions of Gregory Bateson, Michel Foucault (power and knowledge), Geertz (text analogy) and Jerome Bruner (Rico, nd, para. 1).

Within logotherapy, the narrative proposal allows people to express their experiences, their way of being and thinking (White, 1995, p.21), so that self-narrations are considered social ways of offering explanations.

For his part, Bruner (1986) speaks of a genetic inclination towards narrative understanding, in this way, he considers that the stories of our lives are important to make us intelligible. In this sense, narratives are conversational resources, constructions open to a continuous alteration as the interaction progresses (Estrada and Díazgranados, 2007 p.154).

Therefore, the narrative approach within the intervention with groups involves a discursive practice that gives participants the opportunity to use their particular way of speaking and understand their experiences and the effects of these in their lives, as well as the way in which they have marked it. Therefore, in this approach, the function of language enables the construction of contextualized human worlds, giving rise to the subjects constituting their own versions of themselves, the interaction and reality itself (Agudelo and Estrada, 2012, p.375).

\section{The therapeutic tale}

The story within logotherapy is a resource that uses a symbolic-metaphorical language, it is considered a therapeutic story (Rico, s / f, para. 24).
For Fuentes s / f, cited by White (2009), the metaphor of the story (narrative technique used in the applied workshop) appears in contemporary psychotherapeutic discourse in the sense of the story of everyday life. It alludes to discourse as the way in which events and life are explained and given meaning, as well as explains that our stories inform and reform the sources of our knowledge and our perception of reality.

Through stories, people can express their emotions, fears, and anxieties and learn about human feelings. When listening to the narration, connections and reflections are made about what happens inside the story, relating them to their particular situation and mentally organizing their own experience. The culminating point of the story is not the production of it, but the elaboration that the consultant makes of what happened, only he recognizes himself in that new story, which can make it his own and in it can incorporate messages of health and growth (Rico, s / f, par, 22).

\section{The addiction}

For Acevedo (2006), cited by Ortíz (2011), the word addiction derives from the Latin verb "addicted", which translates as adjudicate or designate, that is, it refers to what is assigned or assigned a value that it does not possess. in himself (p.80).

For Martínez, Castellanos, Osorio and Camacho (2015), addiction is a condition that not only crosses the physical dimension, but also the psychological one that includes an existential difficulty, one of the most important aspects being the meaning of life (para. 10) .

On the other hand, addiction is a complex pathology of biopsychosocial origin, its etiology is multiple and it acts in a confusing way to produce addictive disorder. It is developed on the basis of psychological vulnerability, alteration of some brain mechanisms, exposure to environmental factors, chronic consumption and stress (Fundación "Hay Salida", 2020, paragraph 5), which influences the development of identity of the person who suffers it. 
The addition called by Gimeno ( $/ \mathrm{f}$ ) drug addiction, is established where there is an existential void. In order to achieve happiness, the individual tries to replace frustration with an external substitute "drugs or alcohol", which by not providing immediate happiness, a vicious circle is established within. It is then when freedom, responsibility and conscience are blocked, remaining almost hidden; making of drugs and alcohol, the reason and the meaning of the drug addict. (p.5).

\section{The development of the self}

The personality as conceived by Freud, is made up of three main systems: the id, the ego and the super ego, in the mentally healthy person these three systems form a unified and harmonious organization. In the well-adapted person, the self is the executive of reality, dominating and governing the id and the super self (Hall, 1978, pp. 142-149).

From constructionism, the self is understood as a narrative that becomes intelligible within existing relationships. Likewise, from social constructionism, the forms that knowledge of reality and the self take are determined by the influence that social and ideological structures exert on the ways of thinking of the subjects (López-Silva, 2013, pp. 12-15).

Kernberg (1979) cited in Fossa (2009) based on the psychology of the ego, proposed a personality classification, in which the borderline organization of personality is characterized mainly by identity diffusion and ego lability (associated with drug addiction pictures), especially in relationships of great emotional intimacy (p.33-49).

For Stingo, Zazzi, Avigo and Gatti (nd) they are subjects with clear shortcomings in the structuring of personality. With problems such as drug abuse, antisocial disorders, alcoholism, aggressiveness, schizophrenia, ezquisomania or latent schizoparanoia, which could be the analog of border states, with alterations in the following ego functions:

$\begin{array}{ll}- & \text { Autonomy } \\ - & \text { Self-assessment } \\ - & \text { aggression } \\ - & \text { Frustration tolerance } \\ - & \text { Regulation of limits }\end{array}$

$\begin{array}{ll}- & \text { The integration } \\ - & \text { The formation of concepts } \\ - & \text {-Realistic planning }\end{array}$

\section{The meaning of life (from the interpretation of addiction)}

Among the main postulates of logotherapy are freedom of will (which ensures that every subject is able to make personal decisions and enjoy the necessary freedom to choose their own destiny) and the meaning of life (through humanization and personalization) In this context, logotherapy constitutes a perception of the world with a positive root (Pérez and Merino, 2012, paragraphs 4-6).

The meaning of life implies a leap into action, towards commitment, towards a project. The meaning of life is independent of what the person does in her life, therefore there is no meaningless existence; strictly speaking. What exists is the feeling of lack of vital meaning. The meaning of life is carried out in the community through three basic tasks: work-profession, couple-family and social relations-friendship (Ortíz, 2011, p.55-57).

\section{Expectations and purposes}

For Linares ( $/ \mathrm{f}$ ) it is always possible to distance oneself from emotions to investigate the purposes, causes and purposes, among other elements, that give rise to knowledge of addiction, without this meaning denying it (p.129).

The therapeutic objective is for man to act from his potentialities and resources to help himself rediscover and recognize himself in his reality, being himself the protagonist of his therapeutic process. So you have to try to become aware of your own responsibilities, choosing a different lifestyle from the one you have led up to now, accompanied by the therapist and your self-help group.

What used to be to live for and for drugs must now have other expectations such as personal growth, the challenge of living without drugs, being happy and finding meaning in what they live, assuming their own vulnerability and valuing their ability to love (Gimeno, 2004) cited by (Ortíz, 2011, pp. 85-86). 


\section{The family}

Whether a person can maintain a given selfnarration depends above all on the will of others to follow the interpretation of certain past situations in relation to the subject (López-Silva, 2013, p.16).

For Gregori Bateson ( $\mathrm{s} / \mathrm{f}$ ), cited by Agudelo and Estrada (2012) in the constructionist social perspective, it is highlighted that both action and discursive practice are important within group therapy, where for the construction of reality external of the subject, mind, spirit and communication are combined in the external dimension of the body (p.359).

Therefore, Gimeno (s / f) considers that throughout the entire treatment the involvement of the family in the young person's process is very important. Parents, partner and siblings, can mainly participate in it (p.10).

\section{The needs of the addict}

Man, by nature, needs a true, deep and encompassing experience of reality that allows him to discover his own multidimensionally transcendent self with respect to nature, his peers, the world of values, and also with respect to himself same. In turn, the addicted man needs to take refuge in some external element, with omnipotent characters, since he is not able to tolerate frustrations and sufferings by himself (Ortíz, 2011, pp. 78-79).

\section{Coping in the addict}

Working with emotions implies a commitment to oneself and as such, it is considered as a work of personal transformation (Linares, s / f, p.120).

The efforts of addicted patients are more positive when they face the problem of the meaning of life, since drug use is considered a symptom of malaise or existential emptiness experienced by the person who uses it. But it is also in some way the symptom of the social unrest that surrounds her (Ortíz, 2011, p.85).

\section{The meaning}

For social constructionism, reality is a set of conversational meanings that are socially shared (López-Silva, 2013, p. 14).
When someone is confronted about a problem they face, they can provide a possible solution for others in a similar bond. If the conflict of personal history is similar to that of the other, it becomes significant for both (Rico, nd, para 13).

According to Estrada and Diazgranados (2007) the potential of meaning is achieved through complementary action; affirmations alone acquire meaning when another or others coordinate with the emission, complementing it or transforming it, which is why an individual alone cannot mean (p. 318).

Geertz (s / f), cited by Rico (s / f), considers that people's lives are found in texts within texts. He considers the interaction of people as the interaction of readers with respect to certain texts; understands the evolution of lives and relationships in terms of reading and writing texts and warns that recounting an experience establishes the meaning that will be attributed to it (paragraph 9).

\section{Deconstruction}

As Linares (s / f) affirms, even the most agonizing of situations can be overcome. Reflective work on one's own discomfort through self-knowledge and acceptance fosters deep internal coherence (p.125).

The position of the constructionist approach approaches links criticism and deconstruction; where criticism is conceived as the possibility of exploring things in a different way and the type of relationships that could be established from new conceptions about the world and about oneself. In the same way, it proposes that social reality does not need to be as it has currently been (Crespo, 2003) cited by (Sandoval, 2010, p.33-34).

\section{The resignification and emotional state of the addict}

In general terms, resignification is a free and intentional adaptation, characterized by a strong recontextualizing will (Rimoldi, 2012, p.161).

Gergen (s / f) cited by Sandoval (2010) considers that human societies are historically changing, therefore the meanings that people attribute to reality are also changing. 
Likewise, meanings influence the actions and decisions of the people who make up these societies (Pérez and Merino, 2012, p.32).

If the person manages to understand emotionally why she is suffering, her suffering is lightened; If, on the contrary, they do not want to know anything, they tighten up and entrench themselves in the comfort of a problem to which they have become accustomed, then their suffering worsens (Bermúdez, 2013, p.3).

Similarly, Linares (s / f) referring to emotional intelligence (theory proposed by Daniel Goleman) refers to the ability that the subject has to realize the emotions he is feeling and the moment in which they appear, if enables a fruitful dialogue between the subject and his emotional life (p119).

\section{Resources and repair}

Maslow (s / f), cited by Linares (s / f), considers in accordance with the stoic position, that within the human being beats the impulse towards improvement and personal development whose dullness is inhuman and pathologizing, at all costs. person can restore self-confidence and thus put into operation all their potential to face problems (such as addiction) no matter how serious (p.13).

In addition to the above, Martínez, Castellanos, Osorio and Camacho (2015) assert that among the resources of people with addictions as well, there is the ability to be able to look at themselves and monitor and control their own emotional and cognitive processes (paragraph 5).

Similarly, Gimeno (s / f) identifies in logotherapy a proposal that presents a general and comprehensive conception of man that uses important resources such as:

- The capacity called self-distancing; related to the possibility of putting distance in front of external situations not only with the world, but with others.

- The capacity named self-transcendence; that allows him to address someone or something other than himself to make a sense.
From this position, it is firmly believed in the capacities of each one to rediscover themselves as a conscious and responsible individual (p. 4).

\section{Methodology to be developed}

According to Cisterna (2005), the methodological process carried out during this process corresponds to the qualitative paradigm, in which, in addition to the collection of theoretical information, which involved the search, organization, systematization and analysis of information, on logotherapy and resignification ; A focus group was also held with the members of FEIDEP from which the categories of the results of the workshop "The resignification of addiction" emerged.

\section{Process}

To carry out the workshop called "The resignification of addiction", an invitation was first sent to the young people in an annex situation located in Fundación Durango, A. C., who accepted to participate in good spirits.

Once installed, the workshop was carried out with the support of FEIDEP members, following the schedule of moments and activities referred to in the descriptive letter.

To conclude, a focus group was held with the members of FEIDEP, from which a categorization of the information from the workshop was derived, which in turn was triangulated with theoretical data found on the subject investigated, which served as the basis for the presentation of the results and conclusion.

\section{Results}

The experience lived by the young participants was manifested in the richness of their speeches, giving them meaning through the construction and telling of stories.

The results obtained in the application of this workshop were integrated following a logic of obtaining categories with the information obtained, as well as the triangulation of these data with the theory that founded the design of this space for deliberation (Cisterna, 2005, p. $61)$. 
In the results presented below, the perception of young people in a situation of addiction due to addictions is collected; about what has happened in your life.

These results are shown in two parts, in the first the interpretation of what happened due to the addiction experienced is commented and in the second the resignification of it derived from the experienced workshop. Happened

Part One: The Interpretation of What

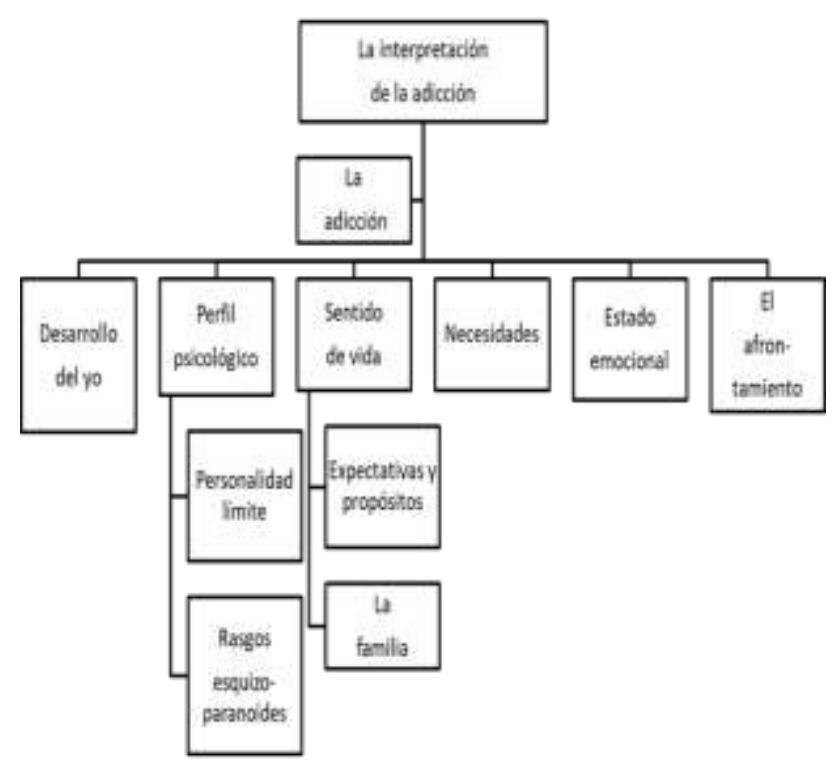

Figure 1 The interpretation of what happened Source: Own Elaboration (2020)

As an effect of logotherapy, the workshop participants had the opportunity to express their interpretation of what happened in relation to the addiction they have been presenting and its repercussions on the development of their self.

Within its narrative elements were detected that allowed, through triangulation with the theoretical contributions, to identify the psychological profile that characterizes them (borderline personality with mainly schizoparanoid traits) represented by lack of integration and structure of what is spoken, verbiage, thought magic, narcissism, marasmus and anxiety.
The central point of the narratives revolved around the construction of the meaning that addiction has had in his life (omnipotence, undifferentiation, desire for power and abandonment of dreams), making clear personal purposes and expectations about the relationship with the family, as well as their present needs and the emotions perceived in the moment, which ultimately resulted in a commitment to coping with the situation they are experiencing; for personal transformation and the achievement of their well-being even though they feel it takes a lot of work to maintain success.

The tendency to addictions in the youth of the state of Durango, Mexico; It is growing. This leads to dysfunctional responses in their interpersonal relationships, due to the loss of impulse control and the difficulty to recognize the consequences derived from the same, admitting addiction as a condition that hinders the development of the self and the sense of life, with difficulty in personal relationships.

In the psychological profile manifested in the young participants, traits related to borderline personality disorder with difficulties in aspects of the development of the "self" are identified, as well as the ability to act according to their criteria (autonomy), when trying to establish relationship between what he is and what he would like to be (self-assessment), to control aggression; with little tolerance for frustration, with difficulty elucidating limits and making realistic approaches.

Self-perception about the meaning of life is related to the meaning that addiction takes on in your life, which manifests itself physically and psychologically and hinders basic activities such as work, family and partner relationships, and social relationships (such as friendship), establishing relationships with reduced purposes. All this caused by the loss of impulse control, not taking responsibility for taking control of what corresponds to him and the difficulty to recognize the consequences of the above; with a leading eagerness that can turn into a negative reality that in turn can give them more than one problem in their daily routine and can also get away from others.

Their need to receive affection and love, especially from their mother and family, is distinguished, one of the areas in which there are most difficulties due to addiction. 
By expressing their life experiences, through the therapeutic story, the participants were able to identify some of their needs in the search for well-being (identify motivations, coping resources, their sense of life, making personal decisions and new possibilities).

Within this workshop, logotherapy has been the ideal strategy to correlate the borderline personality of the addict with his great sensitivity to experiences with the outside, for which they respond with great intensity to any emotion, having presented a fruitful dialogue by middle of the therapeutic tale.

The positive response to participation in the workshop and their attendance with pleasure is one of the signs that speaks of their effort to face the problems they live and for which they are currently in a situation of annexation, despite presenting a feeling of inadequacy and to seek miracle cures.

Finally, regarding the interpretation of what happened and with the support of the following data crossover table.

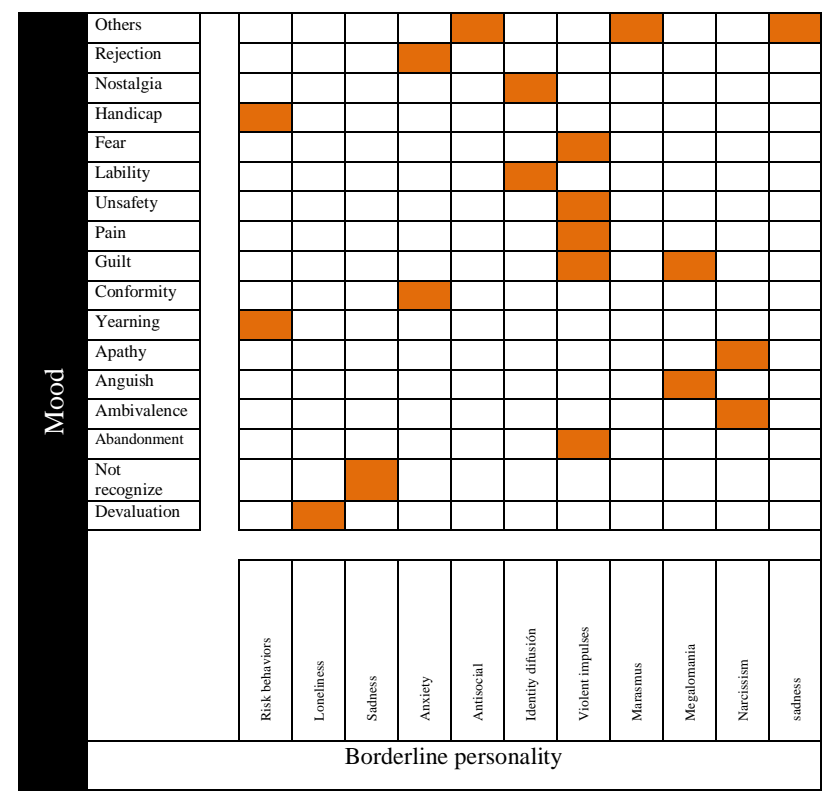

Table 1 Borderline personality and state of mind Source: Own Elaboration (2020)

The tendency to fall into states of mind where pain, guilt and insecurity are mostly involved can be observed, in direct correspondence with the violent impulses wielded in the activities carried out (such as being a hit man).

\section{Second part: The resignification}

The process of resignification experienced in this workshop led the participants to project the possibility of a new dimension of life, by raising awareness of the opportunity to choose, based on the development of the capacity for change, motivations, attitudes and skills. emotional

The results obtained in this second part were categorized into three categories (resources, meaning of life and reparation) as shown in the following figure.

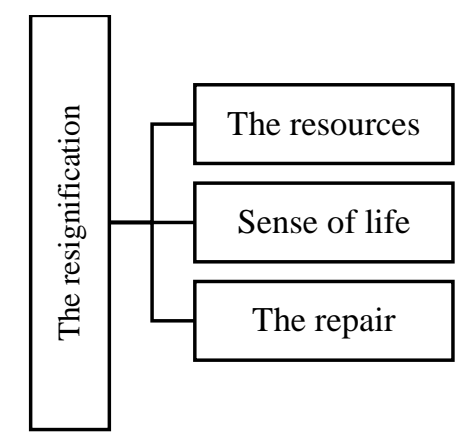

Figure 2 The resignification Source: Own Elaboration (2020)

The self-perception of drug use experienced in the workshop, led the participants to review their life project, managing to externalize resources that can lead them to the crystallization of their desires for well-being, prosperity and achievement of goals related to their sense of life in redress for harm done to themselves and to others.

Logotherapy turns out to be an appropriate therapeutic approach for the treatment of cases related to addictions since by applying conversational resources, young people in a situation of drug addiction have the opportunity to rediscover and recognize themselves in their reality, facilitating them to be the protagonist of.

$\begin{array}{ll}- & \text { The ability to change } \\ - & \text { The resilience } \\ - & \text { Thankfulness } \\ - & \text { Positivity } \\ - & \text { The sense of reality } \\ - & \text { Entrepreneurship } \\ - & \text { Desires for improvement } \\ - & \text { Desires for prosperity and ambition } \\ - & \text { The desire to possess or be } \\ - & \text { Respect }\end{array}$

CEJAS-LEYVA, Luz María, CALDERÓN-PALENCIA, Laura Araceli, VILLAZANA-MARTÍNEZ, Jesús Salvador and HERNÁNDEZ-SÁCHEZ, Eréndira. The resignification as part of logotherapy, for the well-being of young people in a situation of addiction annexation. ECORFAN JournalRepublic of Paraguay. 2020 
The central point of logotherapy is in the construction of meaning and the sense of life for the individual, in interaction with the context that includes a positive perception of the world. In itself it is a rebirth that implies a commitment to dreams and goals, it is a commitment to the life project that must be nurtured with one's own resources.

Likewise, among the main postulates of logotherapy are the freedom of will, to make personal decisions and enjoy the necessary freedom to choose one's own destiny and the meaning of life, in short, your well-being. Significant data in relation to the meaning of life and the resources of young people in a situation of annexation due to additions are presented in the following data crossover table.

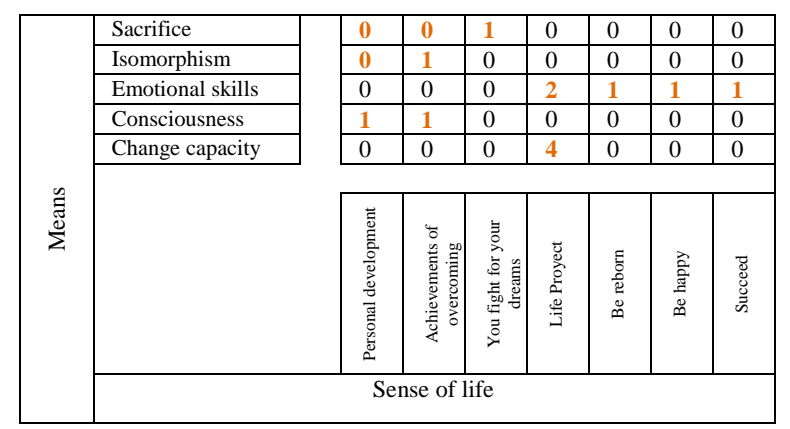

Table 2 Meaning of life and resources Source: Own Elaboration (2020)

Realizing what surrounds addiction and its consequences has allowed the workshop participants to realize their capacity for change, through the development of projects that give meaning to their lives.

An important category that emerged in this analysis is repair, which is considered by the stoic posture, as the impulse towards improvement and personal development that beats in the human being and that can restore self-confidence to everyone and thus put in operation all its potentialities to face problems no matter how serious they are (Linares, s / f, p.13). In this sense, young people in a situation of annexation due to addiction, externalize as a result of guilt, the renunciation of damage and the desire to surrender to overcome themselves, to rediscover themselves and to rebuild their self.

\section{Annexes}

Workshop: The resignification of addiction

Objective: that the participants reflect on their experiences in addictions and consider the consequences and the achievements that these have brought to their lives, through narrative speech therapy activities, which allow them to reconstruct these experiences and redefine the reality that surrounds them.

Participants: 15 young people in a situation of annexation due to addictions.

\section{Duration: 4 hours}

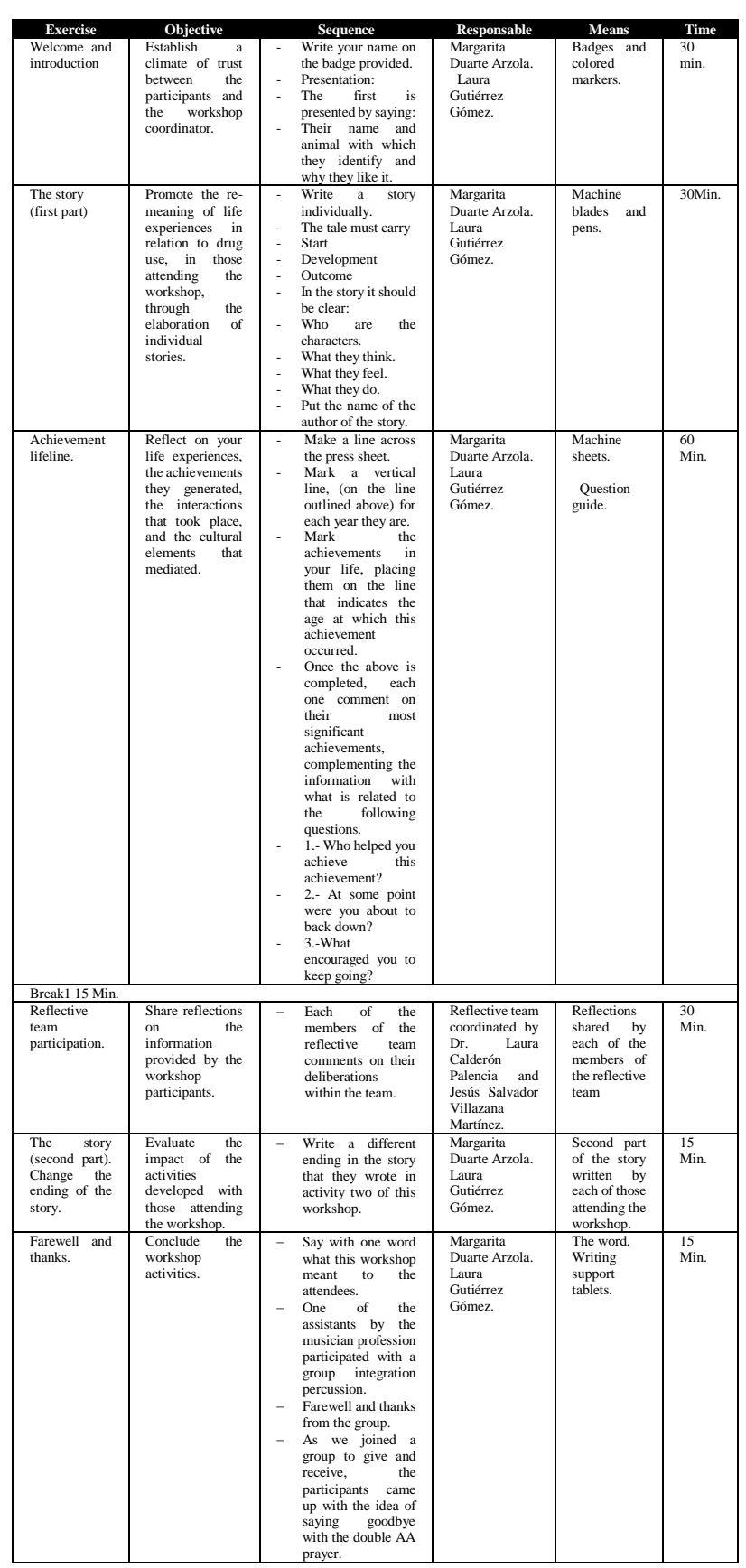

Source: Own Elaboration (2020) 


\section{Thanks}

To Fundación Durango, A. C. for the support provided to carry out the workshop "The resignification of addiction" with young people in an addiction situation.

To the members of: Educational Promotion for the Development of Human Potential SILVESTRE REVUELTAS (FEIDEP) for their participation in the design and implementation of the workshop "The resignification of addition", as well as in the search for references for the preparation of this article.

$\begin{array}{ll}- & \text { Prof. in TFP Cecilia Dalia Heredia } \\ & \text { Nevárez } \\ - & \text { Prof. at PC Eréndira Hernández Sánchez } \\ - & \text { Mtro. in TF Héctor Salvador Gurrola } \\ & \text { Torres } \\ - & \text { Lic. At TCH Ivonne Pérez González } \\ - & \text { Mtro. in TF Jesús Salvador Villazana } \\ & \text { Martínez } \\ - & \text { Dra. In P Laura Araceli Calderón } \\ & \text { Palencia } \\ - & \text { Prof. in TF Leonor Mier Orona } \\ - & \text { Dra. In P Leticia Pesqueira Leal } \\ - & \text { Dra. At GEVH Luz María Cejas Leyva } \\ - & \text { Prof. in TF Ma. del Carmen Rodríguez } \\ & \text { Samaniego } \\ - & \text { Prof. in TF Marcela Leonor Zamora } \\ - & \text { Flores } \\ - & \text { Prof. in TF Margarita Duarte Arzola } \\ - & \text { Prof. in CF María Luisa Lares López } \\ - & \text { Prof. at SC Silvia Irene Rosales Leyva }\end{array}$

\section{Conclusions}

Social constructionism is a theoretical stance that poses for group intervention, a therapeutic exercise that invites participants to retell and coconstruct their stories.

Existence in itself is more than enough for the individual to achieve changes of great magnitude. This position offers the possibility of finding better alternatives to live and think, recognizes the need for intimate contact between the subject and himself as a way to overcome pain, insecurity and guilt for violent impulses in this case.
In addition, the dialogic stance (logotherapy) and their participation in the creation of their own and community meanings put the accent on rich descriptions of life, as is the case of stories made by young people in a situation of addiction annexation.

For Wittgenstein (s / f), cited in White (2009), the narrative self and the socially and dialogically constructed self are reflective. The narratives they use not only reflect life but rather add something. While the resignification is not a copy, but a new dimension of life.

Likewise, the co-construction, between therapist and consultant, opens new paths and offers the opportunity to grow and change, to have confidence in himself and in his potential to not take more drugs and achieve his wellbeing.

\section{References}

Agudelo, B. M.E. y Estrada, A. P. (2012). Constructivismo y construccionismo social: Algunos puntos comunes y algunas divergencias de estas corrientes teóricas Bolivia.. Disponible en:

file:///C:/Users/usuario/Downloads/DialnetCons tructivismoYConstruccionismoSocial-

5857466\%20(3).pdf (Consultado el 3 de noviembre de 2020).

Aristegui, R. (2015). Construccionismo Social y Discusión de Paradigmas en Psicología: Indeterminación, Holismo y Juegos de Lenguaje vs. La Teoría Pictórica del Lenguaje. Chile. ISBN: 978-1-938552-39-7. Disponible en: file:///C:/Users/usuario/Downloads/Aristegui_ Worldshare_Book_07-2015_f\%20(1).pdf (Consultdo el 10 de octubre de 2020).

Cisterna, (2005). Categorización y triangulación como procesos de validación del conocimiento en investigación cualitativa, Ensayo. ISSN 0717-196X. Disponible en: http://www.ubiobio.cl/theoria/v/v14/a6.pdf (Consultado el 9 de noviembre de 2019).

Compiladoras Estrada, M. A. M. y Diazgranados, F. S. (2007). Kenneth Gerben, Construccionismo social, Aportes para el debate y la práctiva. Argentina. Ediciones: Uniandes. ISBN: 978-958-695-301-6. 
Daza, M. J. (1984). Ideología y política en el emperador Marco Aurelio. Alicante, España. ISSN: 0213-2338 0213-2338 Disponible en: DOI 10.14198/LVCENTVM1984.3.13 (Consultado el 7 de noviembre de 2020).

Donoso, N. (2004). Construccionismo Social: Aplicación del Grupo de Discusión en Praxis de Equipo Reflexivo en la Investigación Científica. Santiago de Chile, Chile. ISSN: Disponible en: https://www.redalyc.org/pdf/264/26413102.pdf (Consultado el 27 de abril de 2020).

Fossa, (2009). Organización limítrofe de la personalidad. Santiago de Chile, Chile, ISSN 2145-6569. Disponible en: file:///C:/Users/usuario/Downloads/Dialnet-

OrganizacionLimitrofeDePersonalidad-

3987453.pdf (Consultado el 10 de noviembre de 2020).

Fundación "Hay salida". (2020). La adicción es una enfermedad. Disponible en: https://www.fundacionhaysalida.com/que-es-laadiccion/ (Consultado el 8 de noviembre de 20209).

Gimen, O. J. A. (s/f). Logoterapia y drogas. Disponible en: http://www.fundacioncsz.org/ArchivosPublicac iones/67.pdf (Consultado el 8 de noviembre de 2020).

Guereca, P. (2019). Durango, entre las 8 ciudades con más consumo y venta de drogas: ENSU. Durango, México. Disponible en: (Consultado el 8 de noviembre de 2020).

Hall, C. S. (1978). Compendio de Psicología Freudiana. Buenos Aires Argentina. Editorial: Paidós, $8^{\mathrm{a}}$ Edción. Disponible en: https://www.academia.edu/11980686/Compend io_de_psicolog\%C3\%ADa_freudiana_Calvin_ S_Hall (Consultado el 10 de noviembre de 2020).

Iglesia, M. (s/f). El perdón desde la logoterapia. Disponible en: file:///C:/Users/usuario/Downloads/DialnetElPerdonDesdeLaLogoterapia-7391979.pdf (Consultado el 1 de noviembre de 2020).
Linares, (s/f). Filosofía como terapia, La actitud vital estoica frente al malestar existencial. Tesis doctoral. Universidad de Granada. España. ISBN: 978-84-1306-054-5. Disponible en: https://digibug.ugr.es/bitstream/handle/10481/5 $4521 / 627$

López-Silva, P. (2013).Realidades, Construcciones y Dilemas, Una revisión filosófica al construccionismo social. Manchester, Inglaterra. Disponible en: https://scielo.conicyt.cl/pdf/cmoebio/n46/art02. pdf (Consultado el 31 de octubre de 2020).

Martínez, O. F., Castellanos, C., Osorio, C. C. A. y Camacho, L. S. (2015). Efectos de la logoterapia sobre los recursos personales de las personas con adicción. Argentina. ISSN: 03276716 Disponible en: https://www.redalyc.org/pdf/2819/2819469880 05.pdf (Consultado el 8 de noviembre de 2020).

Ortíz, C. M. Y. (2011). La búsqueda del sentido en el consumo de drogas, inicio y Proceso de rehabilitación en la población del programa Residencial puertas abiertas Santa Ana, Peñaflor, de la Fundación Paréntesis Santiago de Chile. Chile. Tesis doctoral. Disponible en: (Consultado el 10 de noviembre de 2020).

Pérez, P. J. y Merino, (2012). Definición de logoterapia. Disponible en: https://definicion.de/logoterapia/ (Consultado el 8 de noviembre de 2020).

Rico, N. D. (s/f). Hacer psicología, Terapia narrativa y cuentos terapéuticos. ISSN18705618. Disponible en: https://www.uv.mx/psicologia/files/2016/10/ter apianarrativa.pdf (Consultado el 10 de noviembre de 2020).

Rimoldi, L. (2012). El concepto de resignificación como aporte a la teoría de la adaptación teatral.

Argentina.

Disponible en;

file://C:/Users/usuario/Downloads/9927-

Texto\%20de1\%20art\%C3\%ADculo-14118-110-20130527.pdf (Consultado el 9 de noviembre de 2020).

Sandoval, M. J. (2010). Construccionismo, conocimiento y realidad: una lectura crítica desde la Psicología Social. Madrid, España. Disponible en http://www.revistamad.uchile.cl/23/sandoval_0 4 (Consultado el 11 de octubre de 2020).

CEJAS-LEYVA, Luz María, CALDERÓN-PALENCIA, Laura Araceli, VILLAZANA-MARTÍNEZ, Jesús Salvador and HERNÁNDEZ-SÁCHEZ, Eréndira. The resignification as part of logotherapy, for the well-being of young people in a situation of addiction annexation. ECORFAN JournalRepublic of Paraguay. 2020 
Sandoval, M. J. (2010). Construccionismo, conocimiento y realidad: una lectura crítica desde la Psicología Social. Disponible en:file:///C:/Users/usuario/Downloads/Dialnet ConstruccionismoConocimientoYRealidad3656447.pdf (Consultado el 7 de noviembre de 2020).

Stingo, N. r., Zazzi, M. C., Avigo, L. M. y Gatti, C. L. (s/f). El trastorno borderline. Evolución del concepto. Clínica y patología. Argentina. Disponible en: https://www.alcmeon.com.ar/3/12/a12_09.htm( Consultado el 10 de noviembre de 2020).

Traductor Bermúdez, H. L. (2013). Curarse, es dirigir una mirada nueva a sí mismo. Colombia. ISSN 0124-7816. Disponible en: file:///C:/Users/usuario/Downloads/DialnetCurarseEsDirigirUnaMiradaNuevaASiMismo5527447.pdf (Consultado el 9 de noviembre de 2020).

Villatoro, J., Medina-Mora, M. E., Fleiz, B., Moreno, L. M., Natalia Oliva, R. N., Bustos, G. M., Fregoso, I. D., Gutiérrez, L. M. L. y Amador, B. (2012). El consumo de drogas en México: Resultados de la Encuesta Nacional de Adicciones, 2011. México. ISSN: 0185-3325 Disponible en: http://www.scielo.org.mx/scielo.php?script=sci _arttext\&pid=S0185-33252012000600001

(Consultado el 8 de noviembre de 2020).

White, M. (1995). Reescribir la vida, entrevista y ensayos. Barcelona, España. Editorial: Gedisa. ISBN: 84-7432-847-0.

White, M. (2009). Guías para una terapia familiar sistémica, Capítulo 3 Construcción social y práctica terapéutica. España. Editorial: Gedisa. ISBN: 8474324769. Disponible en: 75.pdf? sequence $=4 \&$ is Allowed $=y$ (Consultado el 2 de noviembre de 2020). 